\title{
STRATEGI PEMASARAN DESA WISATA BLIMBINGSARI KABUPATEN JEMBRANA
}

Cristina Ratua.1, I Made Adikampanaa,2

${ }^{1}$ cristina.ldp6@gmail.com, 2adikampana@gmail.com

a Program Studi S1 Destinasi Pariwisata, Fakultas Pariwisata,Universitas Udayana, Jl. Dr. R. Goris, Denpasar, Bali 80232 Indonesia

\begin{abstract}
Village tourism is growing significantly nowadays. It is happening because the transition of mass tourism becomes alternative tourism, which village tourism is a kind of alternative tourism. But, the significant growth of village tourism still facing problem. The problem is about marketing. One of village tourism that facing marketing problem is Blimbingsari Village Tourism. The main objective of this research is to find marketing strategies for Blimbingsari Village Tourism. Data were collected through observation, literature study and interviews the tourism manager that responsible in tourism at Blimbingsari, that is tourism committee. After collecting process, the data analyzed descriptively and analyzed the marketing strategies using the SWOT approach.

The result of analysis showed that strength, weakness, opportunity and threat of Blimbingasri Village Tourism could created strategies that supported the marketing of that village tourism. Based on the analysis through the SWOT approach, the strategies are SO strategy that is packaging of product, WO strategy that is promotion, ST strategy that is repositioning, and WT strategy that is giving the extra service for tourist.
\end{abstract}

Keywords : marketing strategy and village tourism

\section{PENDAHULUAN}

Perkembangan desa wisata di Bali sangat pesat. Hal ini terlihat dari semakin banyaknya desa yang dikembangkan menjadi desa wisata. Hal ini senada dengan yang diutarakan oleh Kepala Dinas Pariwisata Provinsi Bali, Ida Bagus Subhiksu dalam kompas.com 30 Oktober 2013 bahwa :

"Pemda Bali mencanangkan program 100 desa wisata dalam program pembangunan Bali bidang pariwisata selama empat tahun ke depan. Ini untuk mengembangkan destinasi wisata di Bali."

Pernyataan tersebut mengindikasikan bahwa perkembangan jumlah desa wisata di Bali akan mengalami peningkatan terus menerus seiring berjalannya waktu.

Kesadaran wisatawan akan dampak yang terjadi akibat pariwisata massal, terutama dampak negatif yang ditimbulkan membuat terjadinya pergeseran minat dan tren ke arah pariwisata alternatif yang cenderung memperhatikan kualitas pariwisata. Dampakdampak negatif yang ditimbulkan akibat pariwisata massal terjadi di berbagai bidang, yaitu ekonomi, sosial-budaya dan lingkungan. Melihat dampak-dampak tersebut, para stakeholder mulai menggali potensi yang dimiliki oleh setiap daerah dan sebisa mungkin mengolahnya menjadi pariwisata alternatif. Ini merupakan salah satu langkah positif yang baik tentunya dan juga untuk menjadikan pariwisata yang sifatnya berkelanjutan, dimana untuk mencapai pariwisata berkelanjutan dibutuhkan keterlibatan semua stakeholder dalam meminimalisir dampak negatif yang ditimbulkan akibat adanya kegiatan pariwisata.

Salah satu desa yang diresmikan oleh Gubernur Bali sebagai desa wisata pada 15 Desember 2011, yaitu Desa Blimbingsari yang terletak di Kabupaten Jembrana. Desa wisata ini memiliki beragam keunikan yang menarik wisatawan untuk berkunjung. Namun, untuk menarik wistawan agar menikmati segala keunikan yang dimiliki oleh Desa Wisata Blimbingsari tentunya dibutuhkan konsep pemasaran yang jelas dan tepat. Pemasaran menjadi salah satu faktor penting dalam menunjang keberhasilan tujuan desa wisata dalam menjual produk pariwisata yang dimiliki dan meningkatkan kunjungan wisatawan. Namun, pertumbuhan desa wisata yang terjadi, khususnya di Bali ternyata tidak sebanding dengan pemasaran akan desa wisata tersebut, seperti yang diungkapkan oleh Djinaldi Gosana selaku Direktur Bali Community Based Tourism Association (Bali CoBTA) yang merupakan salah satu lembaga non-profit yang mengembangkan desa wisata di Bali. Pernyataan yang diungkapkan dalam tempo.com 30 Mei 2013 bahwa :

"pemasaran memang masih menjadi masalah bagi kami"

Pernyataan tersebut menegaskan bahwa dalam pengembangan desa wisata khususnya yang ada di Bali, kendala yang dihadapi adalah masalah pemasaran.

Bagi Desa Wisata Blimbingsari sendiri, pemasaran memiliki peran penting dalam meningkatkan jumlah kunjungan wisatawan 
melalui pengemasan produk pariwisata yang menunjukkan bahwa produk tersebut memiliki keunikan tersendiri dibandingkan dengan produk pariwisata sejenis yang dimiliki oleh pesaing, sehingga wisatawan dapat menetapkan pilihan untuk mengunjungi Desa Wisata Blimbingsari. Permasalahan yang dihadapi oleh desa wisata seperti Blimbingsari yang identik dengan penduduk beragama Kristen Protestan adalah latar belakang wisatawannya yang didominasi oleh agama Kristen Protestan. Hal ini menjadi masalah karena potensi yang dimiliki oleh Desa Wisata Blimbingsari sebenarnya bisa juga dinikmati oleh wisatawan dari berbagai segmen pasar karena target pasar yang menjadi sasaran Desa Wisata Blimbingsari terbuka bagi siapapun tanpa melihat latar belakang apapun.

Permasalahan ini menunjukkan bahwa betapa pentingnya pemasaran dalam keberhasilan desa wisata mendatangkan wisatawan dan mencapai target pasar yang disasar. Oleh karena itu, tulisan ini berusaha untuk mendalami seperti apa strategi pemasaran yang dapat diterapkan di Desa Wisata Blimbingsari, sehingga hasil yang diperoleh dapat memberikan kontribusi bagi pihak pengelola pariwisata dalam memasarkan produk-produk yang ada di Desa Wisata Blimbingsari.

\section{KEPUSTAKAAN}

\subsection{Tinjauan Penelitian Sebelumnya}

Ada beberapa tinjauan penelitian yang dipakai sebagai bahan perbandingan terkait dengan rumusan masalah. Pertama, penelitian yang dilakukan oleh Erliyanto (2012), yaitu "Strategi Pemasaran The Bush Telegraph di Seminyak Kuta-Bali", yang menjelaskan bahwa dengan menggunakan analisis SWOT dapat diperoleh strategi pemasaran berupa peningkatan promosi, meningkatkan kerjasama dengan banyak travel agent, menjaga kualitas produk makanan dan minuman, menjaga kualitas pelayanan yang baik, menjaga hubungan baik dengan restoran lain dan menambah variasi makanan dan minuman yang disediakan. Persamaan penelitian ini dengan yang sebelumnya terletak pada fokus penelitian, sedangkan perbedaannya pada lokasi penelitian.

Penelitian lain yang digunakan sebagai bahan perbandingan adalah penelitian yang dilakukan oleh Purnamiyanti (2004), yang berjudul "Potensi Goa Maria sebagai Objek Wisata Ziarah di Desa Ekasari Kecamatan Melaya Kabupaten Jembrana". Penelitian tersebut menjelaskan bahwa potensi yang ada di Goa Maria sangat mendudukung untuk menjadikan Goa Maria sebagai objek wisata ziarah. Selain itu, masyarakat setempat dan wisatawan yang berkunjung juga mendukung Goa Maria dijadikan objek wisata ziarah. Penelitian ini memiliki persamaan pada lokasi penelitian, yaitu di Kabupaten Jembrana, sedangkan perbedaannya terletak pada fokus penelittian.

\subsection{Tinjauan Konsep}

\subsubsection{Konsep Strategi Pemasaran}

Strategi pemasaran menjadi sebuah upaya untuk melayani kebutuhan pasar yang menjadi target. Menurut Kotler dan Amstrong (1997), strategi pemasaran adalah :

"pola pikir pemasaran yang akan digunakan oleh unit bisnis untuk mencapai tujuan pemasarannya".

Sedangkan menurut Chandra (2002), strategi pemasaran merupakan :

"rencana yang menjabarkan ekspektasi perusahaan akan dampak dari berbagai aktifitas atau program pemasaran terhadap permintaan produk atau lini produknya di pasar sasaran tertentu."

Berdasarkan kedua konsep tersebut, yang dimaksudkan strategi pemasaran dalam penelitian ini adalah upaya yang dilakukan oleh pengelola pariwisata untuk mencapai target wisatawan yang berkunjung ke Desa Wisata Blimbingsari.

\subsubsection{Konsep Bauran Pemasaran (Marketing Mix)}

Bauran pemasaran menjadi penentu cakupan kegiatan pemasaran yang akan dilakukan. Menurut Kotler dan Keller (2007) bauran pemasaran adalah :

"seperangkat alat pemasaran yang digunakan perusahaan untuk terus menerus mencapai tujuan pemasarannya di pasar sasaran."

Sedangkan menurut Lupiyoadi (2006) bauran pemasaran adalah : 
"alat bagi pemasar yang terdiri atas berbagai unsur suatu program pemasaran yang perlu dipertimbangkan agar implementasi strategi pemasaran dan positioning yang ditetapkan dapat berjalan sukses"

Komponen dalam bauran pemasaran menurut McCarthy (dalam Kotler dan Susanto, 2000) membagi bauran pemasaran menjadi 4 bagian, yaitu :

\subsubsection{Product (Produk)}

Produk adalah penawaran nyata perusahaan pada pasarnya, mereknya dan penyajiannya. Dalam hal ini, produk mencakup mutu, rancangan, ukuran, pelayanan, garansi dan pembelian.

\subsubsection{Price (Harga)}

Harga yaitu jumlah uang yang harus dibayar pelanggan untuk produk itu, dimana harga harus disesuaikan dengan pandangan pelanggan tentang nilainya, supaya pembeli tidak beralih ke pesaingnya. Harga mencakup harga dasar, potongan harga, keuntungan, jangka waktu pembayaran dan syarat pembayaran harga.

\subsubsection{Place (Tempat)}

Tempat adalah berbagai kegiatan perusahaan untuk membuat produknya terjangkau dan tersedia bagi pasar sasarannya. Tempat meliputi saluran, cakupan, lokasi, inventaris dan transportasi.

\subsubsection{Promotion (Promosi)}

Promosi yaitu berbagai kegiatan perusahaan untuk mengkomunikasikan produknya pada pasara sasarannya. Yang termasuk dalam promosi yaitu iklan, hubungan masyarakat dan pemasaran langsung.

\subsubsection{Konsep Pemasaran Pariwisata}

Pengertian pemasaran pariwisata menurut Yoeti (1985:290) adalah:

"seluruh kegiatan untuk mempertemukan permintaan (demand) dan penawaran (supply), sehingga pembeli mendapat kepuasan dan penjual mendapat keuntungan maksimal dengan resiko seminimal mungkin."
Berdasarkan konsep tersebut, maka pemasaran pariwisata dalam hal ini untuk mengidentifikasi kebutuhan dan keinginan wisatawan sehingga dapat memberikan pelayanan yang maksimal kepada wisatawan. Hal ini menjadi sangat penting karena produk pariwisata berbeda dengan produk barang lainnya dan memiliki ciri khas tersendiri.

\subsubsection{Konsep Desa Wisata}

Konsep desa wisata menurut Nuryanti (1993) adalah :

"suatu bentuk integrasi antara atraksi, akomodasi dan fasilitas pendukung yang disajikan dalam suatu struktur kehidupan masyarakat yang menyatu dengan tata cara dan tradisi yang berlaku"

Hal ini dapat diartikan bahwa desa wisata merupakan salah satu cara untuk menikmati atraksi, akomodasi dan fasilitas pariwisata dalam sebuah masyarakat yang masih menjunjung tinggi tradisi yang ada. Dengan demikian, yang menjadi fokus utama dari sebuah desa wisata adalah tradisi asli yang masih menyatu dengan kehidupan masyarakat, sehingga desa wisata tidak dapat dipisahkan dari tradisi.

\section{METODE}

\subsection{Ruang Lingkup}

Batasan yang menjadi lingkup penelitian ini meliputi batasan dari segi lokasi dan batasan dari segi permasalahan. Dari segi lokasi, lingkup penelitian dibatasi di Desa Wisata Blimbingsari yang terletak di Kabupaten Jembrana. Sedangkan lingkup penelitian dari segi permasalahan yaitu strategi pemasaran yang dilakukan di Desa Wisata Blimbingsari. Strategi pemasaran yang dimaksudkan mengacu pada marketing mix (bauran pemasaran) 4P menurut McCarthy (dalam Kotler, 2000), yaitu product, price, place dan promotion. Selain menganalisis bauran pemasaran, guna menemukan strategi pemasaran dalam memasarkan Desa Wisata Blimbingsari, maka digunakan analisis SWOT. Sebagai bentuk aplikatif dari strategi yang telah ditemukan, maka akan terbentuk 
program yang dapat dilakukan untuk mendukung pemasaran Desa Wisata Blimbingsari.

\subsection{Teknik Pengumpulan Data}

Dalam mengumpulkan data yang dibutuhkan, digunakan tiga teknik yaitu wawancara mendalam, observasi dan studi kepustakaan. Wawancara mendalam didahului dengan menentukan informan yang dilakukan dengan purposive sampling, yaitu ditentukan berdasarkan tujuan dan juga pertimbangan tertentu, dimana informan memiliki kriteria mengetahui kedalaman informasi mengenai masalah yang hendak diteliti, dalam hal ini yaitu kedalaman informasi tentang strategi pemasaran di Desa Wisata Blimbingsari.

Observasi yang dilakukan adalah dengan meninjau langsung ke lokasi penelitian, yaitu Desa Wisata Blimbingsari. Observasi ini dilakukan dengan mengamati langsung terhadap keadaan lokasi penelitian, para pelaku pariwisata dan aktivitas pariwisata yang berlangsung di Desa Wisata Blimbingsari, sehingga mendapat gambaran terkait objek penelitian.

Studi kepustakaan yang digunakan untuk mendukung penelitian ini dalam mengumpulkan data yang dibutuhkan adalah melalui penelusuran dokumen penelitian sebelumnya yang memiliki permasalahan sejenis, dan buku literatur tentang strategi pemasaran serta dokumen tentang Desa Wisata Blimbingsari.

\subsection{Teknik Analisis Data}

Mengingat jenis penelitian yang dilakukan merupakan jenis penelitian kualitatif, maka data yang dikumpulkan dianalisis dengan menggunakan metode deskriptif kualitatif. Metode ini dilakukan setelah data yang dibutuhkan telah terkumpul, kemudian disusun secara sistematis dan dijelaskan dengan menggunakan kata-kata sehingga memberikan gambaran yang jelas kepada pembaca. Data yang diolah dengan metode deskriptif kualitatif yaitu data yang diperoleh di lapangan berupa informasi, foto-foto, dokumen-dokumen yang berkaitan dengan keadaan Desa Wisata Blimbingsari dan strategi pemasaran, termasuk mendeskripsikan hasil wawancara dengan pihak pengelola pariwisata Desa Wisata Blimbingsari.

Sebelum melakukan analisa terhadap strategi pemasaran dengan menggunakan pendekatan SWOT, yang perlu dilakukan terlebih dahulu adalah mengidentifikasi bauran pemasaran yang terdapat di Desa Wisata Blimbingsari. Setelah itu, dengan menggunakan pendekatan SWOT, maka dapat dirumuskan strategi yaitu dengan menganalisis kekuatan (strength), kelemahan (weakness), peluang (opportunity) dan tantangan (threat) yang dimiliki oleh Desa Wisata Blimbingsari. Dari strategi-strategi yang telah dirumuskan, akan diperoleh program-program yang dapat dilakukan sebagai bentuk aplikatif dari strategi tersebut.

\section{PEMBAHASAN}

\subsection{Lokasi Penelitian}

Lokasi penelitian dilakukan di Desa Blimbingsari yang berada di Kecamatan Melaya Kabupaten Jembrana. Desa ini bisa ditempuh selama kurang lebih 3 jam dari Bandar Udara Ngurah Rai ke arah Gilimanuk atau sekitar kurang lebih 1 jam dari pelabuhan penyebrangan Gilimanuk menuju Denpasar. Secara geografis, desa ini berbatasan langsung dengan Taman Nasional Bali Barat di sebelah utara dan barat, Desa Ekasari di sebelah timur dan Kecamatan Melaya di sebelah selatan.

Desa yang memiliki jumlah penduduk sebanyak 1.080 jiwa dengan 280 kepala keluarga ini, seluruh penduduknya beragama Kristen Protestan. Sebagian besar penduduk di desa ini bekerja sebagai petani, namun ada juga yang bekerja sebagai PNS, guru dan pegawai swasta. Hasil kebun dari Desa Blimbingsari yaitu coklat, kelapa dan pisang. Di samping itu juga, ada peternakan ayam, sapi dan babi.

Desa ini didirikan pada tahun 1939 oleh seorang misionaris Belanda, dengan dibantu oleh puluhan pengikut orang Bali yang beragama Kristen. Mereka melakukan perambahan hutan demi mewujudkan impian memiliki desa sendiri yang bernuansa Kristen. Maka, tidak berlebihan jika dikatakan bahwa desa ini merupakan desa Kristen pertama di Bali.

Sepintas sepertinya desa ini nyaris tidak ada bedanya dengan desa tradisional 
lainnya di Bali. Pakaian, bahasa bahkan nama penduduk di desa ini juga menggunakan nama Bali. Tentu saja, seperti yang disebutkan sebelumnya bahwa penduduk desa tersebut adalah orang Bali, bukan pendatang dari pulau lain. Jadi, meskipun memeluk agama Kristen, mereka tetap mempertahankan budaya aslinya. Inilah yang membuat desa ini unik dan menarik.

Pada setiap hari raya seperti Natal, masyarakat menyambutnya dengan membuat hiasan penjor di sepanjang jalan desa, dimana penjor merupakan hiasan yang umum digunakan oleh masyarakat Hindu Bali menjelang hari raya Galungan. Kemudian, di saat kebaktian di gereja, umat Kristen yang datang beribadah juga mengenakan pakaian adat Bali. Begitu juga dengan pendeta yang akan memimpin ibadah juga mempergunakan bahasa Bali. Bukan hanya itu saja, bahkan nyanyian di gereja pun diiringi dengan permainan gambelan Bali.

\subsection{Marketing Mix (Bauran Pemasaran) 4.2.1. Product (Produk)}

Produk yang ditawarkan oleh Desa Wisata Blimbingsari berupa keindahan alam, yaitu letaknya yang berdampingan denganTaman Nasional Bali Barat dan pemandangan gunung yang sangat indah. Produk buatan yang dapat dinikmati adalah penataan rumah dengan pola linear mengikuti alur jalan utama desa yang memberikan kesan rapih dan asri. Dari segi budaya dan spiritual yang ditawarkan oleh desa wisata ini adalah perpaduan antara kebudayaan Bali yang sangat kental di tengah-tengah masyarakat yang beragama Kristen Protestan, dimana hal ini terwujud dalam bangunan gereja yang disebut PNIEL yang menggunakan arsitektur asli Bali dengan segala ritual yang bernuansa Bali. Selain itu, produk pariwisata yang ditawarkan bagi wisatawan adalah trekking, bird watching, agrowisata, home industry dan camping.

\subsubsection{Price (Harga)}

Harga yang ditawarkan oleh Desa Wisata Blimbingsari terhadap produk pariwista, tidak ada perbedaan bagi wistawan domestik maupun wisatawan mancanegara. Untuk harga akomodasi, berkisar antara Rp.200.000Rp.500.000/malam. Sedangkan untuk harga makanan yang disajikan bagi wisatawan, mulai dari Rp.20.000Rp.45.000. Desa Wisata Blimbingsari juga menyediakan jasa penyewaan sepeda dengan harga Rp.100.000/sepeda per hari. Bagi wisatawan yang ingin menikmati pertunjukan Tari Jegog yang merupakan khas Jembrana, maka wisatawan bisa membayar Rp.1.000.000-Rp.1.500.000 untuk 10100 orang. Ini sangat cocok untuk dinikmati bagi wisatawan yang datang secara berkelompok.

\subsubsection{Place (Saluran Distribusi)}

Untuk menikmati produk pariwisata yang ditawarkan di Desa Wisata Blimbingsari, yang menjadi saluran penghubung bagi wisatawan untuk mengaksesnya adalah dengan memanfaatkan kemajuan teknologi yaitu internet yang akan memudahkan wisatawan untuk melakukan reservasi akomodasi dan produk buatan lainnya. Namun, untuk menikmati produk alami yang ditawarkan, wisatawan harus datang langsung ke Desa Wisata Blimbingsari dan harus merasakan hidup bedampingan dengan masyarakat lokal serta merasakan langsung dalam segala aktivitas keseharian masyarakat.

\subsubsection{Promotion (Promosi)}

Dalam mempromosikan Desa Wisata Blimbingsari kepada wisatawan, media promosi yang dipergunakan adalah website. Selain melalui media elektronik, media cetak pun digunakan yaitu berupa brosur. Untuk lebih memaksimalkan promosi yang dilakukan, pihak pengelola pariwisata juga menjalin kerjasama dengan travel agent, kementrian pariwisata, universitas-universitas dan juga gereja-gereja. 


\subsection{Analisis SWOT Pemasaran Pariwisata di Desa Wisata Blimbingsari}

Tabel 1. Matrik Analisis SWOT di Desa Wisata Blimbingsari

\begin{tabular}{|c|c|c|}
\hline $\mathrm{C}^{\text {IFAS }}$ & $\begin{array}{l}\text { Strenghts (S) } \\
\text { - Kerjasama dengan universitas } \\
\text { - Komite Pariwisata } \\
\text { - Akulturasi } \\
\text { - Kealamian desa } \\
\text { - Sejarah yang unik } \\
\end{array}$ & $\begin{array}{l}\text { Weaknesses(W) } \\
\text { - Minim konten website } \\
\text { - Minim tenaga profesional } \\
\text { - Tidak memiliki website sendiri } \\
\text { - Minim kerjasama dengan } \\
\text { universitas lainnya. } \\
\end{array}$ \\
\hline $\begin{array}{l}\text { Opportunities (O) } \\
\text { - Lokasi dekat pelabuhan dan TNBB } \\
\text { - Akomodasi disediakan masyarakat } \\
\text { - Kemajuan teknologi } \\
\text { - Dibawahi oleh CoBTA } \\
\text { - Event pariwisata di Bali } \\
\text { - Pengembangan desa wisata oleh } \\
\text { pemerintah } \\
\text { - Adanya media pariwisata }\end{array}$ & $\begin{array}{l}\text { Strategi SO : } \\
\text { Strategi pengemasan produk }\end{array}$ & $\begin{array}{l}\text { Strategi WO } \\
\text { Strategi promosi }\end{array}$ \\
\hline $\begin{array}{l}\text { Threats (T) } \\
\text { - Jauh dari pusat ibukota propinsi } \\
\text { - Jauh dari bandara udara } \\
\text { - Dikenal sebagai desa wisata untuk } \\
\text { Kristen saja } \\
\text { - Persaingan } \\
\text { - Similarity product } \\
\text { - Harga akomodasi masih mahal }\end{array}$ & $\begin{array}{l}\text { Strategi ST } \\
\text { Strategi repositioning }\end{array}$ & $\begin{array}{l}\text { Strategi WT } \\
\text { Strategi memberikan pelayanan } \\
\text { ekstra bagi wisatawan }\end{array}$ \\
\hline
\end{tabular}

\subsubsection{Strengths (Kekuatan)}

Kekuatan yang dimiliki oleh Desa Wisata Blimbingsari untuk bertahan dan bersaing dengan desa wisata yang lain adalah menjalin kerjasama dengan universitas dalam hal makanan dan minuman yang disajikan bagi wisatawan serta penataan kamar di akomodasi, memiliki pengelola pariwisata berupa komite paiwisata, menawarkan akulturasi antara budaya Hindu Bali dengan agama Kristen, kealamian desa yang masih terjaga, serta memiliki sejarah yang unik.

\subsubsection{Weaknesses (Kelemahan)}

Kelemahan yang menjadi hambatan bagi pemasaran dan peningkatan jumlah kunjungan ke Desa Wisata Blimbingsari adalah masih kurangnya informasi menarik yang ada di website tentang detail produk Desa Wisata Blimbingsari, belum memiliki website sendiri karena website yang ada saat ini masih dikelola oleh CoBTA, kurangnya tenaga profesional dalam bidang pariwisata, dan masih kurang menjalin kerja sama dengan universitas-universitas yang memiliki program kepariwisataan.

\subsubsection{Opportunities (Peluang)}

Peluang yang dimiliki dalam meningkatkan jumlah kunjungan wisatawan ke Desa Wisata Blimbingsari adalah dekat dengan pelabuhan penghubung Pulau Jawa dan Pulau Bali yaitu Pelabuhan Gilimanuk, dekat dengan destinasi wisata Taman Nasional Bali Barat, adanya dukungan masyarakat dengan menyediakan rumahnya sebagai akomodasi wisatawan, adanya kemajuan teknologi yang akan mempermudah proses pemasaran, memiliki dukungan dari lembaga non-profit yaitu CoBTA, adanya event-event yang bertaraf nasional maupun internasional yang diselenggarakan di Bali sehingga bisa dijadikan kesempatan untuk mempromosikan desa wisata ini, adanya rencana pemerintah untuk mengembangkan 100 desa wisata di Bali, dan adanya media-media pariwisata yang dapat dijadikan sarana promosi seperti $\mathrm{TV}$, radio dan surat kabar. 


\subsubsection{Threats (Ancaman)}

Ancaman yang menimbulkan kerugian bagi Desa Wisata Blimbingsari dalam persaingan adalah lokasinya yang jauh dari pusat kota Denpasar, jauh dari terminal wisatawan yaitu Bandar Udara Ngurah Rai, anggapan orang yang mengatakan sebagai desa wisata bagi umat Kristen saja, berdekatan dengan destinasi wisata lain sehingga menimbulkan persaingan, memiliki produk yang sama dengan desa wisata lain, dan harga akomodasi yang masih tergolong mahal bagi sebagian orang.

\subsection{Strategi dan Program-Program Pemasaran Desa Wisata Blimbingsari}

Berdasarkan kekuatan, kelemahan, peluang dan ancaman yang dihadapi oleh Desa Wisata Blimbingsari, maka dapat dirumuskan strategi yang bisa diterapkan dalam pemasaran desa wisata ini, beserta dengan program-program yang aplikatif sebagai pendukungnya. Adapun strategistrategi dan program-program yang dimaksud adalah sebagai berikut :

Tabel 2. Matrik Strategi dan Program Pemasaran Desa Wisata Blimbingsari

\begin{tabular}{|c|c|c|}
\hline No & Strategi & Program \\
\hline 1 & Pengemasan produk & $\begin{array}{l}\text { - Bekerjasama dengan travel agent dalam mengemas } \\
\text { produk } \\
\text { - Mengemas sejarah desa wisata dalam bentuk visual } \\
\text { - Melibatkan masyarakat lokal dalam merancang } \\
\text { pengemasan produk } \\
\text { - Memiliki tim profesional dalam bidang pariwisata }\end{array}$ \\
\hline 2 & Promosi & $\begin{array}{l}\text { - Ikut berpartisipasi dalam event pariwisata } \\
\text { - Membuat akun desa wisata Blimbingsari di media sosial } \\
\text { - Menjalin kerjasama dengan media lokal untuk promosi } \\
\text { - Memasang billboard Desa Wisata Blimbingsari di jalan- } \\
\text { jalan utama } \\
\text { - Membuat website yang dikelola oleh pihak pengelola di } \\
\text { Desa Wisata Blimbingsari } \\
\text { - Menjalin kerjasama dengan universitas-universitas di Bali }\end{array}$ \\
\hline 3 & Repositioning & $\begin{array}{l}\text { - Memperbaharui image untuk memperluas target pasar } \\
\text { - Menonjolkan sisi lain dari desa wisata ini } \\
\text { - Menganggarkan dana khusus untuk pemasaran desa } \\
\text { wisata } \\
\text { - Menjalin kerjasama dengan destinasi wisata di sekitar. }\end{array}$ \\
\hline 4 & $\begin{array}{l}\text { Memberikan pelayanan } \\
\text { ekstra bagi wisatawan }\end{array}$ & $\begin{array}{l}\text { - Menjalin hubungan dengan pelanggan } \\
\text { - Melakukan penjemputan langsung terhadap wisatawan } \\
\text { - Memberikan potongan harga bagi wisatawan yang sudah } \\
\text { sering berkunjung } \\
\text { - Memberikan kartu ucapan kepada wisatawan saat } \\
\text { kembali ke daerah asalnya } \\
\text { - Mengirimkan kartu ucapan selamat ulang tahun atau } \\
\text { ucapan hari raya beserta brosur promo produk } \\
\text { pariwisata. }\end{array}$ \\
\hline
\end{tabular}

\subsubsection{Strategi Pengemasan Produk}

Produk pariwisata yang dimiliki oleh Desa Wisata Blimbingsari, dikemas dengan lebih menarik dan melibatkan banyak pihak dalam pengemasan produk tersebut.

\subsubsection{Strategi Promosi}

Melakukan promosi dengan menggunakan peran media, internet dan perkembangan teknologi serta ikut terlibat dalam event-event pariwisata yang diselenggarakan di Bali.

\subsubsection{Strategi Repositioning}

Menggali dan menemukan potensi lain yang dimiliki oleh desa wisata sehingga memperluas target pasar.

\subsubsection{Strategi Memberikan Ekstra Bagi Wisatawan}


Memberikan perhatian lebih kepada setiap wisatawan yang berkunjung aga dapat memberikan kenangan tersendiri bagi wisatawan sehingga dapat melakukan kunjungan kembali ke desa wisata.

\section{PENUTUP}

\subsection{Kesimpulan}

Keterbatasan pasar masih menjadi masalah bagi pihak pengelola Desa Wisata Blimbingsari. Oleh karena itu, dengan menganalisis kekuatan, kelemahan, peluang dan ancaman yang dihadapi oleh Desa Wisata Blimbingsari dengan menggunakan analisis SWOT, maka diperoleh strategi pemasaran yang bisa diterapkan, yaitu strategi pengemasan produk, strategi promosi, strategi repositioning dan strategi memberikan pelayanan ekstra bagi wisatawan. Strategi-strategi yang telah dirumuskan, dapat diterapkan dalam memasarkan Desa Wisata Blimbingsari, serta memaksimalkan segala potensi untuk mendatangkan lebih banyak lagi wisatawan yang berkunjung ke desa wisata ini.

\subsection{Rekomendasi}

Rekomendasi yang bisa diberikan dalam memajukan pemasaran di Desa Wisata Blimbingsari adalah memperbaharui terus informasi yang diberikan kepada wisatawan, menciptakan keakraban dengan wisatawan, membangun kerjasama dengan travel agent dan instansi pemerintahan maupun swasta, serta belajar dari desa lain yang sudah berhasil dalam pemasaran.
DAFTAR PUSTAKA

Chandra, Gregorius. 2002. Strategi Program Pemasaran. Edisi pertama. Penerbit ANDI Yogyakarta.

Erliyanto, Juli. 2012. Strategi Pemasaran The Bush Telegraph di Seminyak Kuta-Bali. Laporan Akhir. Program Studi Pariwisata Universitas Udayana Denpasar

Gosana, Djinaldi. 2013. Desa Wisata di Bali Terkendala Pemasaran. TEMPO, 30 Mei 2013, diakses tanggal 24 Januari 2015

Kotler, Philip. 2002. Manajemen Pemasaran. Jakarta: PT Prenhallindo

Kotler, Philip. 2002. Manajemen Pemasaran Perhotelan dan Kepariwisataan. Edisi ke II. Jakarta: PT Prenhallindo

Kotler, P. dan A.B. Susasnto. 2000. Manajemen Pemasaran di Indonesia. Jakarta : Salemba Empat.

Kotler P. dan Gary Armstrong. 1997. Principles of Marketing. Singapore: Prentice Hall International Editions.

Kotler, P. dan K.L. Keller. 2007. Manajemen Pemasaran, Edisi keduabelas Jilid 1. Penerbit PT. Indeks, 444 halaman.

Lupiyoadi, Hamdani.2006. Manajemen Pemasaran Jasa. Edisi Kedua. Jakarta: Penerbit Salemba Empat.

Nuryanti, Wiendu. 1993. Concept, Perspective and Challenges, makalah bagian dari Laporan Konferensi Internasional mengenai Pariwisata Budaya. Yogyakarta: Gajah Mada University Press. Hal. 2-3.

Purnamiyanti, Ni Luh Tanti. 2004. Potensi Gua Maria sebagai Objek Wisata Ziarah di Desa Ekasari Kecamatan Melaya Kabupaten Jembrana. Laporan Akhir. Program Studi Pariwisata Universitas Udayana Denpasar

Rangkuti, Freddy. 2002. Analisis SWOT Tehnik Membedah Kasus Bisnis. Jakarta: PT Gramedia Pustaka Utama.

Suwena, I Ketut dan I Gst Ngr Widyatmaja. 2010. Pengetahuan Dasar Ilmu Pariwisata. Denpasar: Universitas Udayana Press

Subhiksu, Ida Bagus. 2013. Bali Kembangkan 100 Desa Wisata. kompas.com, 30 Oktober 2013, diakses 24 Juni 2014

Website resmi Desa Wisata Blimbingsari, www.cbtbali.org/blimbingsari-village, diakses 24 Juni 2014

Yoeti, Oka A. 1996. Pemasaran Pariwisata. Bandung : Angkasa Bandung. 